\title{
Lomotil poisoning in children
}

\author{
J. A. CURTIS AND K. M. GOEL
}

Royal Hospital for Sick Children, Glasgow

SUMMARY 45 children were admitted to hospital after ingesting varying quantities of diphenoxylate (Lomotil). One died and 44 recovered without any sequelae. Four patients were comatose, 32 were drowsy, and 9 suffered respiratory depression. No correlation was found between ingested dose and the severity of symptoms. Because of its action in rendering the gut atonic, removal of diphenoxylate by gastric lavage is mandatory, even in patients admitted at least 24 hours after drug ingestion. Naloxone is the narcotic antagonist of choice, and should be used in all cases where suspected diphenoxylate poisoning leads to respiratory depression or coma. The use of Lomotil as an antidiarrhoeal agent in children is difficult to justify.

Diphenoxylate (Lomotil), widely used for the symptomatic relief of diarrhoea, was first marketed in America in 1961, each tablet or $5 \mathrm{ml}$ of syrup containing diphenoxylate hydrochloride $2.5 \mathrm{mg}$ and atropine sulphate $0.025 \mathrm{mg}$ (Ginsburg, 1973). The atropine was added to discourage narcotic abuse by causing unpleasant effect in excessive dose. It was first marketed in the United Kingdom in 1963. Although there are few adverse reactions in adults, Lomotil may result in serious toxicity in children. Effects from the atropine are often present for about 3 hours until the narcotic-like actions of diphenoxylate hydrochloride begin to predominate. Respiratory depression is the most dangerous development and should be treated with narcotic antagonists and other supportive measures. The purpose of this paper is to present 45 cases of Lomotil poisoning in children and to describe its management.

\section{Patients and methods}

Between September 1966 and March 1978, 45 children ( 28 boys and 17 girls) were admitted to hospitals in Glasgow with Lomotil poisoning (Figure). Ages ranged between 10 months and $6 \frac{3}{4}$ years, with a mean of $2 \frac{1}{2}$ years. The number of children from social classes $I$ to $V$ were $4,14,11,8$, and 8 respectively. In only 6 cases was the Lomotil prescribed for a diarrhoeal illness in the child and in 4 of these the child took an accidental overdose. In $30(67 \%)$ cases the Lomotil had been prescribed for

Royal Hospital for Sick Children, Glasgow

J. A. CURTIS, senior registrar

K. M. GOEL, consultant paediatrician an adult relative, but in the other 9 children it was not known for whom the Lomotil was prescribed.

The clinical features of Lomotil poisoning in our patients are given in Table 1. These, on clinical grounds, were divided into three groups, according to whether the symptoms were mild, moderate, or severe. Those mildly affected had features of atropinism only-namely tachycardia, flushing, pyrexia, mydriasis, urinary retention, restlessness, and excitement. Those with moderate symptoms were drowsy and may also have had respiratory depression, while those classified as severely affected were unconscious. Using these criteria, 2 patients were unaffected, 7 were mildly, 32 moderately, and 4 were severely poisoned (Table 2). An average of 3 hours elapsed between ingestion of the drug and onset of symptoms. No correlation was found between the dose ingested and severity of symptoms. In fact, the mean dose of diphenoxylate and atropine was greater in the group with mild symptoms $(2.9$ and 0.029 $\mathrm{mg} / \mathrm{kg})$ than in those moderately affected $(2 \cdot 3$ and $0.023 \mathrm{mg} / \mathrm{kg}$ ), while in the severely poisoned group the dose of diphenoxylate and atropine ranged from 0.77 to $10 \mathrm{mg} / \mathrm{kg}$ and 0.007 to $0.10 \mathrm{mg} / \mathrm{kg}$ respectively. One patient in the last group, a 2-year-old

Table 1 Clinical features in 45 cases of Lomotil poisoning

\begin{tabular}{llll}
\hline $\begin{array}{l}\text { Due to atropine } \\
\text { sulphate }\end{array}$ & $\begin{array}{l}\text { No. of } \\
\text { patients }\end{array}$ & $\begin{array}{l}\text { Due to diphenoxylate } \\
\text { hydrochloride }\end{array}$ & $\begin{array}{l}\text { No. of } \\
\text { patients }\end{array}$ \\
\hline Tachycardia & 25 & Drowsiness & 32 \\
Restlessness/ & & Vomiting & 20 \\
$\quad$ anxiety & 22 & Respiratory depression & 9 \\
Flushing & 20 & Coma & 4 \\
Urinary retention & 7 & Abdominal pain/ & 4 \\
Diminished reflexes & 6 & constipation & \\
& & &
\end{tabular}




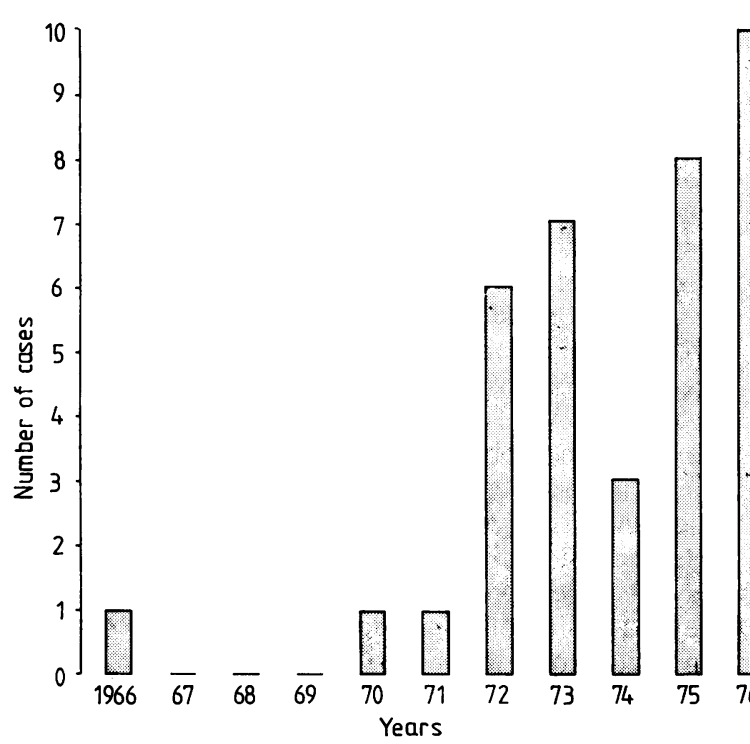

boy, ingested possibly 27 Lomotil tablets (5.6 $\mathrm{mg} / \mathrm{kg}$ diphenoxylate and $0.05 \mathrm{mg} / \mathrm{kg}$ atropine) at 7 p.m. He apparently showed no ill effects 3 hours later and so his parents put him to bed. He could not be roused the next morning at 10 a.m. and was found to be deeply comatose with laboured breathing on admission. His level of consciousness and respirations improved after $5 \mathrm{mg}$ nalorphine IV but, 3 hours later without having regained consciousness, he had a respiratory arrest and was ventilated. Despite hourly injections of $0.08 \mathrm{mg}$ naloxone IV he showed no subsequent response, his condition being marked by deepening coma and papilloedema. He died 48 hours after admission. Necropsy examination showed atropine in the liver 4 days after drug ingestion. Of the 9 children with respiratory depression, 2 required continuous ventilatory support. 40 patients had gastric lavage performed but, in the

Table 2 Severity of symptoms of Lomotil toxicity

\begin{tabular}{|c|c|c|c|c|c|c|}
\hline \multirow[t]{2}{*}{ Symptoms } & \multirow{2}{*}{$\begin{array}{l}\text { Patients } \\
(n=45)\end{array}$} & \multirow{2}{*}{$\begin{array}{l}\text { Age range (years) } \\
\text { (mean) }\end{array}$} & \multicolumn{3}{|c|}{ Dose ingested $(\mathrm{mg} / \mathrm{kg})$} & \multirow{2}{*}{$\begin{array}{l}\text { Outcome } \\
\text { (recovered } n=44)\end{array}$} \\
\hline & & & & Range & Mean & \\
\hline None & 2 & $6 \frac{8}{4}$ & $\begin{array}{l}\text { Diphenoxylate } \\
\text { Hydrochloride } \\
\text { Atropine sulphate }\end{array}$ & & $\begin{array}{l}2 \cdot 04^{*} \\
0 \cdot 02^{*}\end{array}$ & Recovered \\
\hline Mild & 7 & $\begin{array}{l}110 / 12-31 / 12 \\
(23 / 12)\end{array}$ & $\begin{array}{l}\text { Diphenoxylate } \\
\text { Hydrochloride } \\
\text { Atropine sulphate }\end{array}$ & $\begin{array}{l}0.62-5 \cdot 8 \\
0.006-0.05\end{array}$ & $\begin{array}{l}2.9 \\
0.029\end{array}$ & Recovered \\
\hline Moderate & 32 & $\begin{array}{l}13 / 12-42 / 12 \\
(26 / 12)\end{array}$ & $\begin{array}{l}\text { Diphenoxylate } \\
\text { Hydrochloride } \\
\text { Atropine sulphate }\end{array}$ & $\begin{array}{l}0.25-8.4 \\
0.002-0.084\end{array}$ & $\begin{array}{l}2.3 \\
0.023\end{array}$ & Recovered \\
\hline Severe & 4 & $\begin{array}{l}10 / 12-21 / 12 \\
(18 / 12)\end{array}$ & $\begin{array}{l}\text { Diphenoxylate } \\
\text { Hydrochloride } \\
\text { Atropine sulphate }\end{array}$ & $\begin{array}{l}0 \cdot 77-10 \cdot 0 \\
0 \cdot 007-0 \cdot 10 \\
\end{array}$ & $\begin{array}{l}4 \cdot 7 \\
0.047 \\
\end{array}$ & $\begin{array}{l}1 \text { Died } \\
3 \text { Recovered }\end{array}$ \\
\hline
\end{tabular}

*Age and amount ingested not known in one patient.

fatal case, this was not carried out until 26 hours after the drug was ingested. Five patients were given nalorphine $(2-35 \mathrm{mg})$ and 3 naloxone $(0.08 \mathrm{mg})$ as a narcotic antidote, with beneficial effects on respiratory state or level of consciousness in each case. Of those poisoned, 37 made a full recovery within 24 hours while the remaining 6 were drowsy for a longer period.

\section{Discussion}

Of the 45 patients admitted between 1966 and 1978, $29(64 \%)$ were admitted during the last 5 years. This trend occurred despite attention being drawn to the dangers of Lomotil intoxication (British Medical Journal, 1973). Lomotil is an effective and safe drug for the treatment of diarrhoea in adults

A 
(Wasserman, 1974). Its safety for young children, however, is open to question. While the amount of atropine sulphate is very small for the adult patient, children can develop atropinism even with normal dosage (Wasserman et al., 1975). Furthermore, in children there is a very narrow range between therapeutic and toxic dosage and they may exhibit an intolerance to the drug (Bovier-Lapierre et al., 1973; Scorza et al., 1974). We were unable to find a correlation between the severity of symptoms and the dose ingested. Because of this it is not possible to predict what dose will be toxic in children, and while some may have only the mildest symptoms with relatively large doses, others develop severe toxicity on ingesting an amount near the normal dose. In our series in each group of poisoned patients there were children who had ingested small and some who had taken relatively large amounts of the drug (Table 2). Furthermore, analysis of reported cases of Lomotil intoxication confirms the absence of any relationship between the ingested dose and the intensity of subsequent symptoms (Table 3). This is also evident in considering the fatal cases where one patient succumbed to a dose of $5.6 \mathrm{mg} / \mathrm{kg}$ diphenoxylate, while the patient cited by Ginsburg and Angle (1969) ingested only $1.3 \mathrm{mg}$ during a $24-$ hour period. Because of its action in rendering the gut atonic, Lomotil is slowly absorbed once peak plasma levels are reached (at 2 hours) and its excretion is prolonged by an enterohepatic circulation (Karim et al., 1972). Therefore delay in onset and recurrence of symptoms are both features of overdosage (Henderson and Psaila, 1969; Riley, 1969; Wheeldon and Heggarty, 1971). Because of the difficulty in predicting the clinical outcome, all children who have ingested Lomotil in excess, or who show features of toxicity from therapeutic amounts of the drug, must be admitted for observation for a period of at least 24 hours.

The diagnosis of Lomotil poisoning is not aided by the laboratory as the rapid conversion of diphenoxylate to diphenoxylic acid renders it undetectable in blood or urine although atropine may be detectable in biological fluids. Our patient who died had traces of atropine in the liver 4 days later, but diphenoxylate was not detectable in any of the biological fluids. Therefore lack of laboratory detection has some major implications for treatment of suspected Lomotil poisoning. However all patients suspected of Lomotil poisoning must have gastric lavage performed, irrespective of the length of time after ingestion and of whether or not emesis has occurred, to ensure maximum gastric emptying (Rumack and Temple, 1974). Activated charcoal may adsorb diphenoxylate and can be left in the stomach in a dose of $2 \mathrm{~g} / \mathrm{kg}$ (Corby et al., 1970). The administration of an emetic is probably undesirable because of the rapidity with which the patient may become apnoeic and drowsy, thus increasing the possibility of aspiration. Although atropine is removed from the body more rapidly by forced diuresis, this is an ineffective way of increasing diphenoxylate excretion (Way, 1968). Similarly there is no evidence that haemodialysis, peritoneal dialysis, or exchange transfusion will adequately remove significant quantities of diphenoxylate or its metabolites. The appearance of either respiratory depression or drowsiness is the signal for the use of a narcotic antagonist. Naloxone is the drug of choice as it does not cause respiratory depression (Evans et al., 1973). The recommended dose of naloxone is 0.005 to $0.1 \mathrm{mg} / \mathrm{kg}$ given intravenously, intramuscularly, or subcutaneously and this dose may be repeated at intervals of 2-3 min according to clinical response. Since its duration of action is much exceeded by that of diphenoxylate it may need to be given frequently as its effect tends to diminish after about 2-3 hours. Therefore overdoses should be treated promptly with gastric lavage, and intensive monitoring of the patient's respiratory and conscious state during the first $\mathbf{2 4}$ hours is mandatory.

As in $67 \%$ of our cases Lomotil had been prescribed for an adult relative, parents should be instructed to keep the drug out of the reach of

Table 3 Summary of reported cases of Lomotil poisoning

\begin{tabular}{|c|c|c|c|c|c|c|}
\hline Authors & Year & $\begin{array}{l}\text { Cases } \\
(n=79)\end{array}$ & $\begin{array}{l}\text { Age range } \\
\text { (mean) }\end{array}$ & No. of tablets & Diphenoxylate & $\begin{array}{l}\text { Outcome } \\
\text { (recovered } n=74)\end{array}$ \\
\hline Harries and Rossiter & 1969 & 1 & 2 years & 12 & $2 \cdot 4$ & Died \\
\hline Ginsburg and Angle & 1969 & 1 & 5 years & $8 \frac{1}{2}$ & $1 \cdot 2$ & Died \\
\hline Rumack and Temple & 1974 & 16 & $\begin{array}{l}6 / 12-46 / 12 \\
(19 / 12)\end{array}$ & $\frac{1}{2}-40$ & $\begin{array}{l}0 \cdot 18-7 \cdot 4 \\
(2 \cdot 7)\end{array}$ & $\begin{array}{l}1 \text { Died } \\
15 \text { Recovered }\end{array}$ \\
\hline Wasserman et al. & 1975 & 16 & $\begin{array}{l}7 \text { weeks- } 6 \text { years } \\
\text { ( } 22 \text { months) }\end{array}$ & $\begin{array}{l}2-150 \\
(32)\end{array}$ & & $\begin{array}{l}1 \text { Died } \\
15 \text { Recovered }\end{array}$ \\
\hline Our series & 1979 & 45 & $\begin{array}{l}10 \text { months-6 } \\
\text { years }(26 / 12)\end{array}$ & $\begin{array}{l}2-40 \\
(14)\end{array}$ & $\begin{array}{l}0 \cdot 25-10 \mathrm{mg} \\
(2 \cdot 8)\end{array}$ & $\begin{array}{l}1 \text { Died } \\
44 \text { Recovered }\end{array}$ \\
\hline
\end{tabular}

Lomotil one tablet $/ 5 \mathrm{ml}$ contains diphenoxylate $2.5 \mathrm{mg}$ plus atropine sulphate $0.025 \mathrm{mg}$.

* Details of individual cases not given in the paper. 
children and any remaining tablets should be returned to the chemist as soon as the illness is over. Some of our patients took tablets which had been prescribed some time before by the general practitioner. Needless to say, the doctor should prescribe these tablets in limited quantities.

Although the manufacturers indicate that Lomotil is contraindicated in children under age one year, we doubt if it has any place in the treatment of diarrhoea in children.

We are grateful to our colleagues for allowing us to study patients under their care.

Paper given at the Summer Meeting of the Scottish Paediatric Society held at Ninewells Hospital, Dundee, 2 June 1978.

\section{References}

Bovier-Lapierre, M., Frédérich, A., Gillet, P. J., Hartemann, E., and Jeune, M. (1973). Four cases of severe intolerance to 'Diarsed' (Diphenoxylate) in infants. Pediatrie, 28, 71-81.

British Medical Journal (1973). Editorial: Lomotil intoxication in children. British Medical Journal, 2, 678-679.

Corby, D. G., Fiser, R. H., and Decker, W. J. (1970). Reevaluation of the use of activated charcoal in the treatment of acute poisoning. Pediatric Clinics of North America, 17, 545-556.

Evans, L. E. J., Roscoe, P., Swainson, C. P., and Prescott, L. F. (1973). Treatment of drug overdosage with naloxone, a specific narcotic antagonist. Lancet, 1, 452-455.

Ginsburg, C. M. (1973). Lomotil (diphenoxylate and atropine) poisoning. American Journal of Diseases of Children, 125, 241-242.
Ginsburg, C. M., and Angle, C. R. (1969). Diphenoxylateatropine (Lomotil) poisoning. Clinical Toxicology, 2, 377-382.

Harries, J. T., and Rossiter, M. (1969). Letter: Fatal lomotil poisoning. Lancet, 1, 150.

Henderson, W., and Psaila, A. (1969). Lomotil poisoning. Lancet, 1, 307-308.

Karim, A., Ranney, R. E., Evensen, K. L., and Clark, M. L. (1972). Pharmacokinetics and metabolism of diphenoxylate in man. Clinical Pharmacology and Therapeutics, 13, 407419.

Riley, I. D. (1969). Letter: Lomotil poisoning. Lancet, 1, 373.

Rumack, B. H., and Temple, A. R. (1974). Lomotil poisoning. Pediatrics, 53, 495-500.

Scorza, P., Baroneelli, G., Contarini, A., Lombard, S., Miano, A., Salvagiani, L., and Santini, G. F. (1974). Intolerance and intoxication with dephenoxylate hydrochloride. Clinical Pediatrics, 56, 255-266.

Wasserman, G. S. (1974). Antidiarrhoeal agent can be toxic to children. Journal of American Medical Association, 230, 14.

Wasserman, G. S., Green, V. A., and Wise, G. W. (1975) Lomotil ingestions in children. American Family Physician, 11, 93-97.

Way, E. L. (1968). Distribution and metabolism of morphine and its surrogates. In The Addictive States, Association for Research into Nervous and Mental Disease Research Publication, volume 46, p. 13 . Edited by A. Wikler. Williams and Wilkins: Baltimore.

Wheeldon, R., and Heggarty, H. J. (1971). Diphenoxylate hydrochloride (Lomotil) poisoning in children. Archives of Disease in Childhood, 46, 562-563.

Correspondence to Dr K. M. Goel, Royal Hospital for Sick Children, Yorkhill, Glasgow G3 8SJ.

Received 12 July 1978 